\title{
The Multiculturalism Act and Refugee Integration in Canada
}

\author{
Fernando G. Mata
}

From the scope of federal government work, this document sketches some legal, administrative and policy related aspects of the 1988 Multiculturalism Act with regard to their linkages to the refugee integration process in Canada.

\section{Introduction}

In Canada in the 1990s, refugees arrive in a society characterized by a high degree of ethnic and cultural diversity. In 1986, those Canadians who reported origins other than British and French represented about 38 percent of the total population. By 1991, out of a total population of 27.3 million, 42 percent of Canadians reported ethnic origins other than British or French-representing a 20 percent increase from 1986. Census statistics also point out the increasing linguistic and cultural diversity in the country; in 1991, 15 percent of Canadians had a first language other than English or French, and about 16 percent were born outside Canada. It is estimated that by the year 2016, the diversity of the population will increase by 5 percent among school-aged children, 30 percent among members of the labour force and 40 percent among the senior population (Statistics Canada 1993).

Canada currently receives approximately 250,000 immigrants and refugees annually, or one percent of its population, ostensibly to maintain its population level in the face of declining birth rates. Since the mid-1980s, Canada has also experienced significant increases in the volume of refugee claims. The number of claims between 1983 and 1986 jumped from 6,000 to 18,000 . In 1990 , about 36,000 claims were received while the volume

Fernando G. Mata, PhD, is a Policy Research Officer for the Race Relations and CrossCultural Understanding Program of the Department of Canadian Heritage, Ottawa. diminished in 1991 to approximately 31,000 . In the years to come, immigration is likely to continue to be an important aspect of Canadian society.

Throughout the years, sustained immigration has contributed to Canada's diversity. Early settlers came primarily from the U.S., Britain and other European countries. In recent decades, there has been a major shift in the sources of immigration to Canada. By the 1980s, two out of three people coming to Canada originated from Africa, Asia, the Caribbean or Latin America. Most of these immigrants could be described as visible minorities. In 1986, visible minorities accounted for 6.3 percent of Canada's population. With the tendency of recent immigrants and refugees to settle in major Canadian cities, visible minorities account for close to one-fifth of the population in these cities. Demographers forecast that by the year 2000 , they will make up 10 percent of Canada's total population, and possibly one-third of the population in major centres.

In the context of the present refugee integration process in Canada, it is important to explore the effectiveness of a culturally pluralist legal framework-such as that of the $1988 \mathrm{Multi-}$ culturalism Act and its derived policies-in facilitating the refugee integration process. The Act formally commits the Government of Canada to assist all communities and institutions in bringing about equal access and participation for all Canadians in the economic, social, cultural and political life of the country. The purpose of this paper is to reflect on the Act and its bearing on some aspects of the refugee integration process in Canada.

\section{Historical Background to the Act}

For the first 75 years following Canadian Confederation in 1867, Canadians assumed that ethnocultural minorities ought to be assimilated into the dominant British or French cultures. For much of that period minority ethnocultural communities were ignored and marginalized from mainstream Canadian life. This exclusionary attitude extended to Canadian immigration policy, which favoured British, Americans and Europeans and firmly discouraged immigrants from other countries. As a result, the proportion of Canadians of non-French and non-British origin rose relatively slowly, from approximately 8 percent of the population at the time of Confederation to just over 20 percent by 1951.

In 1947, the Canadian Citizenship Act was introduced, giving Canadians their own citizenship for the first time, and providing all Canadian citizenswhether citizens by birth or by choice-equal status with respect to their rights and obligations. In the following years, Canada, like many other nations, committed itself to extending the principles of equal treatment and respect for diversity throughout the world by ratifying various United Nations treaties. In the late 1960s, Canada's Immigration Act was changed to eliminate preferences based on national origin or race. In essence the new immigration policy removed discriminatory provisions, shifting from an emphasis on economic priorities to one which included humanitarian and social goals such as family reunification, the admission of refugees and the integration of immigrants.

During the 1960s, there was an awakening within Canada to the unequal treatment accorded to the two major language groups. Hearings were conducted across the country. The Royal Commission on Bilingualism and Biculturalism heard the aspirations of ethnocultural communities other than British and French. Canadians of Eastern European origin-particularly from the Western provinces 
-argued that their cultural and economic contributions to the country should be recognized. The Report of the Royal Commission led to passage of the Official Languages Act in 1969 and to the announcement of Canada's first multiculturalism policy.

Canada's first multiculturalism policy was announced in Parliament in 1971. Its main aims were: (1) to help minority communities preserve and share their language and culture; (2) to remove the barriers they faced to full participation in civic society; and (3) to assist new immigrants in their adaptation process. The Multiculturalism Directorate took over existing programming relating to the longterm integration of immigrants and introduced programs to encourage cultural retention. These changes were established to increase awareness among Canadians of the contributions made by people of all backgrounds to Canadian society.

By the early 1980s, the Canadian public realized that the ethnic and cultural diversity of the country was a fundamental and irreversible characteristic of Canadian society. The economic, political, social and cultural dimensions of multiculturalism were acknowledged and a new emphasis was placed on the principle of equality and participation.

There was also a growing need to take affirmative action against discrimination (e.g. employment equity) and to build consensus for acceptance of these measures. The growing cultural and racial diversity of Canada's population reinforced the obsolescence of an assimilationist or "meltingpot" philosophy in social policy.

\section{The Multiculturalism Act}

In 1988, Canada's Parliament unanimously passed the world's first national multiculturalism legislation, the Canadian Multiculturalism Act.

This Act established a new type of multiculturalism policy. The succinct statement of the policy is included its preamble:

to preserve and enhance the multicultural heritage of Canadians while working to achieve the equality of all Canadians in the economic, social, cultural and political life of Canada.

The 1988 Multiculturalism Act declares that the intentions of the government policy are to:

(a) recognize and promote the understanding that multiculturalism reflects the cultural and racial diversity of Canadian society and acknowledges the freedom of all members of Canadian society to preserve, enhance and share their cultural heritage;

(b) recognize and promote the understanding that multiculturalism is a fundamental characteristic of $\mathrm{Ca}$ nadian heritage and identity and that it provides an invaluable resource in the shaping of Canada's future;

(c) promote the full and equitable participation of individuals and communities of all origins in the continuing evolution and shaping of all aspects of Canadian society and assist them in the elimination of any barrier to such participation;

(d) recognize the existence of communities whose members share a common origin and their historic contribution to Canadian society, and enhance their development;

(e) ensure that all individuals receive equal treatment and equal protection under the law, while respecting and valuing their diversity;

(f) encourage and assist the social, cultural, economic and political institutions of Canada to be both respectful and inclusive of Canada's multicultural character;

(g) promote the understanding and creativity that arise from the interaction between individuals and communities of different origins;

(h) foster the recognition and appreciation of the diverse cultures of Canadian society and promote the reflection and evolving expressions of those cultures;

(i) preserve and enhance the use of languages other than English and French, while strengthening the status and use of the official languages of Canada; and (j) advance multiculturalism throughout Canada in harmony with the national commitment to the official languages of Canada.

The Act also declared that all federal institutions should:

(a) ensure that Canadians of all origins have an equal opportunity to obtain employment and advancement in those institutions;

(b) promote policies, programs and practices that enhance the ability of individuals and communities of all origins to contribute to the continuing evolution of Canada;

(c) promote policies, programs and practices that enhance the understanding of and respect for the diversity of the members of Canadian society;

(d) collect statistical data in order to enable the development of policies, programs and practices that are sensitive and responsive to the multicultural reality of Canada;

(e) make use, as appropriate, of the language skills and cultural understanding of individuals of all origins; and

(f) generally, carry on their activities in a manner that is sensitive and responsive to the multicultural reality of Canada.

The Multiculturalism Act emphasizes the principle of building inclusiveness in Canadian society. Section 27 of the 1982 Canadian Charter of Rights and Freedoms guarantees this inclusiveness through the preservation and enhancement of Canada's multicultural heritage. The Act complements the policies designed to achieve an equitable representation of minorities in the workplace, such as the 1986 Employment Equity Act. However, there are important differences between the 1986 Employment Equity Act and the 1988 Canadian Multiculturalism Act. Multiculturalism policy goes beyond the workplace and relies solely on a political accountability mechanism (i.e., the Annual Report to Parliament) while employment equity legislation focuses on the workplace and has a built-in enforcing or regulatory accountability element. 


\section{Federal Multicultural Programming}

In 1991, legislation was passed creating a federal Department of Multiculturalism and Citizenship. This Department, however, was shortlived. In the fall of 1993, it was dismantled and subsumed under the larger Department of Canadian Heritage. Despite these organizational changes, as part of the Citizens Participation and Multiculturalism Branch, multicultural programs continue to encourage the appreciation of the Canadian identity and participation in Canadian life. These programs provide technical and financial assistance to voluntary groups for ongoing activities and projects addressing Canada's ethnocultural diversity and the elimination of barriers to participation in Canadian society, and focus on the promotion of change in Canada's governmental, legal, educational, health, cultural and other institutions so that they adapt more quickly to diversity.

Programs such as the Heritage Cultures and Languages Program help newcomers and first generation Canadians to express their heritage, and foster appreciation and understanding of other cultures. The Community Support and Participation Program targets its funding to first generation Canadians who have post-settlement difficulties integrating into Canadian society. In the area of race relations, the Race Relations and Cross-Cultural Understanding Program promotes the elimination of racism and racial discrimination. It works with businesses, labour organizations, the police, the judicial system, educators and school boards.

It should be noted that the federal multiculturalism programs' mandate extends only to those first generation Canadians experiencing "long-term" integration (postsettlement) related problems. Although the programs do not have a legal or administrative mandate over refugees per se, they carry out their integration role by seeking partnerships with different levels of government, non-profit organizations and immigrant serving agencies which also provide services to refugees. These organizations are involved in integration issues affecting refugees such as language training, race relations and human rights. The federal multiculturalism programs have participated in initiatives related to mental health issues affecting refugees and refugee children, and access of refugees to social services.

The funding and coordination of multiculturalism programs at the provincial and municipal levels complement the programs available at the federal level. The broad concept of multiculturalism is reflected in the variety of policies now in place in each Canadian province.

\section{The Act and Refugee Integration}

Integrating refugees into Canada means working toward finding societal solutions which will make them participants in a more harmonious societal whole (Thomas 1992). From a longitudinal perspective, the integration of refugees is an ongoing process that extends from arrival in the host country, to initial settlement, citizenship acquisition and beyond. As a societal subgroup, refugees aspire to "bridge" these stages, assume self-sufficiency and rapidly integrate into community life (Lanphier and Lukomskyj 1992).

Leaving behind violent conflict and political persecution creates in refugees a strong need for developing cognitive and emotional bonds within the new social milieu. Available statistics in Canada show that immigrants and refugees from non-traditional source countries are more likely to become citizens than those coming from traditional source countries, suggesting that the acquisition of citizenship is regarded as a proxy for political integration. For instance, immigrants from Iran spend an average of five years before acquiring Canadian citizenship. This average is similar for immigrants from El Salvador, Korea, China, the Philippines, Egypt and Hong Kong. Several of these are refugee producing countries. In contrast, immigrants from the U.S. and the U.K. spend an average of 10 years or more in Canada before acquiring Canadian citizenship (DeVries 1992).

The Multiculturalism Act ties the concept of cultural diversity to citizenship values, customs or symbols. In a summary fashion, the following are the three major direct and indirect impacts of the Act on the refugee integration process in Canada:

\section{Recognizing the Cultural Diversity of Refugees}

The first premise of the Multiculturalism Act is that it recognizes the diversity of all Canadians with regard to race, national or ethnic origin, colour and religion as a fundamental characteristic of Canadian society. Cultural diversity is seen as a permanent and central reality, not as something transient or outside the mainstream. The diversity of Canada (expressed clearly in its refugee population) is not seen as a liability but as an asset to nationbuilding. Furthermore, the Act encourages individuals and communities to express this diversity in cultural as well as in economic, social and political terms. To ensure that these expressions are possible, the entire society (including its major institutions and government) is encouraged to change its institutional make-up and organizational culture.

\section{Elimination of Racial Discrimina- tion and Other Participation Barriers}

Another significant aspect of the Multiculturalism Act is the emphasis placed on the elimination of all forms of discrimination (racial, ethnic or religious) and the removal of participation barriers in order to avoid the marginalization of new Canadians (e.g., immigrants and refugees). Refugee groups are particularly vulnerable to different forms of occupational, educational, economic and political marginalization in Canadian society. Marginalization impedes participation in civic life and leads to alienation, a sense of "disenfrarichisement" and feelings of "powerlessness." 
The key goal of the multiculturalism policies and their supporting federal, provincial and local programs is to prevent the marginalization of minorities. Racial discrimination is a contributing factor to this marginalization. The Act stresses the benefits of living in a multicultural society, the dangers of racism and the problems faced by refugees and other minorities in adjusting to Canadian society. So much importance is placed on the values of racial harmony and tolerance that the federal government has commemorated March 21 as the International Day for the Elimination of Racial Discrimination. A public education campaign, known as the March 21 Anti-Racism Campaign, has brought the message of achieving a racism-free society to schools, the workplace and the general public.

\section{The Provision of Culturally Sensitive Services}

The Act formally recognizes the need to provide adequate and culturally sensitive services. Language and cultural barriers between providers and recipients of services are responsible for the under-utilization of the social services and infrastructure available to the immigrant and refugee populations. Federal multiculturalism programming is presently funding projects aimed at promoting multicultural health care, multilingual interpreter services and the production of service manuals in the major languages spoken in Canada.

The Multiculturalism Secretariat (situated within the Multicultural Programming of the Department of Canadian Heritage) has coordinated actions with other institutions such as the Immigration and Refugee Board (IRB) in order to ensure that the policy has been implemented in all institutions dealing with an immigrant/refugee clientele. The IRB's cross-cultural sensitivity workshops help Board members to recognize cultural barriers that can prevent claimants from presenting their cases effectively in hearings. At present, the Board provides claimants with a copy of different religious texts to take their oaths at hearings and makes translation/interpretation services available in 33 languages for people claiming refugee status.

\section{Today's Refugees are Tomorrow's Citizens}

In summary, the 1988 Multiculturalism Act's approach to diversity is based on a set of fundamental values and principles which allow immigrants and refugees to identify with Canadian society. These values are, in essence: (1) inclusive; (2) welcoming; (3) understanding of cultural differences; (4) protective of individual and collective rights; and (5) aimed at the promotion of a social ethos based on equality and participation. These values are extremely important vis-à-vis the present and future participation of refugees in the collective system of symbolic rewards in society (Breton 1987) and in the need to affirm the principles of cultural, economic and political security all along the different stages of the integration process.

As Canada moves into the twenty first-century, it is faced with strong challenges to nation-building in a culturally diverse society. Despite its incremental effect on society, there is still some distance between the objectives set out in Canada's multiculturalism policy and changing political, demographic and economic realities. In addition, the 1988 Multiculturalism Act and similar legal, administrative and social expressions of the Canadian cultural pluralist model are under "siege" due to internal pressures and the attack of those who see the restoration of an assimilationist or meltingpot model as the only viable alternative for Canada (McLellan and Richmond 1993; Abu-Laban and Stasiulis 1992).

The task of reconciling equality and cultural pluralism involves political risks. However, reconciling cultural diversity, national goals and national identity are the most critical challenges of the 1990s for Canada and other nations adhering to the governing philosophy of pluralism, democratic values and tolerance.

\section{References}

Abu-Laban, Y. and Stasiulis, D. 1992. "Ethnic Pluralism Under Siege: Popular and Partisan Opposition to Multiculturalism." In Canadian Public Policy XVIII(4):365-86.

Berry, J.W. 1990. "Some Psychological and Cultural Implications of Multiculturalism: A Social Cost-Benefit Analysis from the Perspective of the Larger Society." Ottawa: Economic Council of Canada, June 27.

Breton, R. 1987. "Symbolic Dimensions of Linguistic and Ethnocultural Realities." In Ethnic Canada: Identities and Inequalities. Toronto: Copp Clark Pittman Ltd.

Breton, R., Isajiw, W., Kalbach, W. and Reitz, J. 1990. In Ethnic Identity and Equality. Toronto: University of Toronto Press.

DeVries, J. 1992. "Becoming a Canadian Citizen." Report produced for Social Trends and Analysis Directorate of the Secretary of State. Ottawa: Multiculturalism and Citizenship Canada.

Lanphier, C.M. and Lukomskyj, O. 1992. "Settlement Policy in Australia and Canada: Immigrant and Refugee Experiences." In conference volume, Immigration and Refugee Policy: The Australian and Canadian Experiences. Centre for Refugee Studies, York University.

McLellan, J. and Richmond, A.H. 1993. "Multiculturalism in Crisis: A Postmodern Perspective of Canada." Forthcoming in Ethnic and Racial Studies 17.

Multiculturalism and Citizenship Canada. 1993. "Operation of the Canadian Multiculturalism Act." Annual Report 1991-92. Ottawa: Minister of Supply and Services.

—. 1992. "Cultural Autonomy in the Constitution and Practice: The Canadian Model." Paper prepared for the symposium, Living Together in a Multicultural State. Organized by the Bertelsmann Foundation of Gütterslch, Germany, September 22-23.

Statistics Canada. 1993. "Population Projections of Ethnic Groups in Canada to the Year 2016." Teega Research, Statistical Supplement. Catalogues 93-315 and 94-237.

Thomas, D. 1992. "The Social Integration of Immigrants in Canada." In S. Globerman (ed.) The Immigration Dilemma. The Frazer Institute. $\square$
March 21
The International Day for the Elimination of Racial Discrimination. 